of some 700 papers, ytoted with full titles, together with the page numbers in the text to which they refer. This is far more useful to a reader than an author index.

The book is written with great lucidity and is well produced with only very few and very minor misprints apparent. The synthesis achieved in this book will be a most valuable asset to those actively working on bone, but it should have a wider appeal in other fields, for example in nuclear medicine, radiotherapy, cancer research and radiation protection. This work will remain an authoritative and enlightening guide to the long term researches that are going on in many laboratories on the effects of skeletal irradiation.

F. W. SPIERS

\section{Animal Sociology}

Organisation in Animal Communities: Experimental and Naturalistic Studies of the Social Behaviour of Animals. By Hilary O. Box. Pp. 251. (Butterworth: London, March 1973.) £5 cloth; $£ 2.50$ paper.

This book, which grew out of a course of lectures given to psychology students at the University of Reading, touches upon a wide range of behavioural phenomena which can loosely be described as social in the sense that in some way they concern interactions between animals. There are descriptions of the social life of many animals and the book is a quite useful, although cursory, account of some of the work which has been done on social behaviour. "Social" is taken very broadly, and mimicry and parasitism are among the subjects undertaken. In addition there are sections on the influence of early experience, particularly deprivation of various sorts, on subsequent social responses, a chapter on communication and a brief survey of the social behaviour of some domesticated animals. The effects of overcrowding and the role of behaviour in the determination of animal numbers are also discussed.

Detailed and comprehensive coverage of all these topics is clearly impossible in only 251 pages, but even with this space limitation, one would have thought that there should have been room to discuss certain important questions which are in fact omitted or not faced squarely. For example, it is surprising that in a chapter which compares insect and human societies, there should be :.o mention of the fact that the apparent "altruism" shown by many of the social insects is probably related to the uniquely close genetic relationship between individuals in a colony ${ }^{1}$. To say that "We now accept that social relationships have facets of both com- petition and mutual aid" (page 6) without discussing such variables as the degree of genetic relationship within a social group simply sidesteps important questions of how natural selection works.

In short, this book has been written by a psychologist, and it shows.

\section{MARIAN DAWKINS}

${ }^{1}$ Hamilton, W. D., Am. Nat., 97, 354 (1963).

\section{Limited Omnivorousness}

Seed to Civilization: The Story of Man's Food. (A Series of Books in Biology.) By C. B. Heiser jun. Pp. xii 243 . (W. H. Freeman: San Francisco and Reading, July 1973.) $£ 3.60$ cloth ; $£ 1.50$ paper.

MAN can appropriately be described as omnivorous. Nevertheless, like other animals, his selection of food is influenced by the complex web of compulsions by which his behaviour is moulded. That is to say, he is subject to the natural history of the species. This is as true today as it ever was. As Professor Heiser points out at the beginning of his book, there is no reason to assume that we are any more intelligent now than were the people who invented agriculture ten thousand years ago. It is, therefore, not surprising that even after having described, for the benefit of the general reader for whom this popular exposition is intended, a varied selection of fact and opinion he reaches the conclusion that "the explanations of why and how man 'invented' agriculture ... are far from certain".

The valuable substance of the book is contained in the chapters in which the origin as human food of the species of animals and plants selected for domestication is described. There is an interesting narrative of what is known of the dog's becoming in 8400 BC man's dumb friend, with a charming illustration of a clay figure from Mexico of a dog specially fattened on maize for the table. The history of the sheep as mutton goes back eleven millenia and the goat about as far. Cattle came later although aurochs, it seems, were worshipped for a long time before they were eaten. The stories of the more exotic animals, the turkey and the Muscovy duck from the Americas, the guinea pig, and the llama from Peru, are narrated as well. It is not surprising that Heiser, a botanist, devotes forty-eight pages to an excellent chapter about grasses, ranging from wheat to bamboo. This chapter, like the rest of the book, is well illustrated with drawings and photographs from many parts of the world and many periods of history. Other chapters deal with legumes, roots, the coconut and odds and ends such as the Cruciferae, comprising a dozen forms from cabbages to rutabaga, with gourds, nuts, coffee and pepper.

All this is informative, interesting, wide-ranging and well suited for the students of general biology, economic botany, anthropology and home economics at whom, according to the publishers, the book is aimed. A three-page chapter about nutrition is less satisfactory and seems a whit perfunctory. That the only table in it should be of the amino acid contents of various proteins owes more to today's fashion than to the major priorities of physiological need. But it is in his last chapter that we leave behind such delights as the account of the breadfruit, Artocarpus altilis, and the troubles that Captain Bligh encountered in transporting 1,000 young breadfruit trees from Tahiti to the West Indies (he succeeded in the end). Instead, there come the all-too-familiar illthought-out adumbrations about the population explosion and the "corrupt, inefficient and unstable governments" from which hungry nations suffer. There are quotations from strings of those pessimistic books, mostly written by chemists and biologists, about what "government" should do to succour developing nations. Not everyone agreed with all the rude things that Professor Wilfred Beckerman had to say about the blunders of chemists and biologists when they ignore the existence of political economy as a well established discipline in its own right; but enough of them were sufficiently incontrovertible, one would have thought, to discourage otherwise well-judging authors like Professor Heiser from allowing their feelings to draw them away from the topics upon which they are worth reading to the ritual obeisance to the starving millions.

MAGNuS PYKe

\section{Development}

Developmental Biology: Its Cellular and Molecular Foundations. By Maurice Sussman. (Foundation of Modern Biology Series.) Pp. xvi 297. (Prentice-Hall: Englewood Cliffs, NJ, and Hemel Hempstead, March 1973.) $£ 3.50$ paper.

DR Sussman's book is written in an engaging and buttonholing style that has the vigour (and the jokes) that will be familiar to those who have heard him lecture. This inimitable style is admirably suited to his purpose which is to demonstrate "the extraordinary power of science as a method of asking questions properly and answering them with rigour." Much of the book is written in the Socratic tradition as interpreted by modern molecular biologists and provides an excellent and compelling introduction to this approach as well as to 